\title{
Reproductive performance and fetal growth in female mice from lines divergently selected on the basis of plasma IGF-1 concentrations*
}

\author{
C. Kroonsberg† $\uparrow$, S. N. McCutcheon†, R. A. Siddiqui†, \\ D. D. S. Mackenzie†, H. T. Blair†, J. E. Ormsbył, B. H. Breier§ and \\ P. D. Gluckman§ \\ $\dagger$ Department of Animal Science, and $\ddagger$ Small Animal Production Unit, Massey University, \\ Palmerston North, New Zealand; and §Developmental Physiology Laboratory, Department of \\ Paediatrics, University of Auckland Medical School, Auckland, New Zealand
}

\begin{abstract}
Summary. Reproductive performance, mammary gland weight and plasma concentrations of insulin-like growth factor-1 (IGF-1) were examined in 18-day-pregnant mice from lines divergently selected on the basis of plasma IGF- 1 concentration. Females of the high IGF-1 (H) line were 14\% heavier than those of the low IGF-1 (L) line at mating but did not differ in conception rate during a 15 -day mating period. $\mathrm{H}$-line females produced significantly larger litters by an average of 1.5 fetuses $(19 \%)$, heavier fetuses $(7 \%)$, greater total fetal weight $(30 \%)$, heavier placental discs $(15 \%)$, greater total placental weight $(35 \%)$ and heavier mammary glands $(18 \%)$. Plasma IGF-1 values were $12 \%$ greater in $\mathrm{H}$ line than L-line females at Day 19 of gestation but the line difference was not significant. It is concluded that differences between the lines in litter size and mammary gland weight are most likely due to differences in maternal bodyweight (which are in turn a consequence of selection for plasma IGF-1 at puberty). Whether the difference in fetal weight is a function of fetal capacity to grow in utero or ability of the dam to provide nutrients for fetal growth is yet to be determined.
\end{abstract}

Keywords: insulin-like growth factor-1; conception; litter size; fetus; mammary gland; mouse

\section{Introduction}

The development of lines of mice divergently selected on the basis of litter mean concentrations of insulin-like growth factor-1 (IGF-1) in plasma has been reported by Blair et al. $(1987,1989)$. High (H) and Low (L) IGF-1 lines were selected on the basis of plasma IGF-1 concentrations at 42 days of age while the Control $(\mathrm{C})$ line was randomly bred. After 7 generations, the divergence between the $\mathrm{L}$ and $\mathrm{H}$ lines in plasma IGF- 1 concentrations and liveweight at 42 days of age was about $20 \%$ and $25 \%$ respectively (Blair et al., 1989). Differences between these lines in liveweight and plasma IGF-1 have been observed as early as 21 days of age and persist until maturity (R. A. Siddiqui, H. T. Blair, S. N. McCutcheon, D. D. S. Mackenzie, P. D. Gluckman \& B. H. Breier, unpublished data).

During the course of these studies it became apparent that there were also differences between the lines in litter size. These could be accounted for by a direct effect of plasma IGF-1 on reproductive performance or by an association between reproductive capacity and maternal body size. However, litter size is difficult to assess directly in mice because of maternal cannibalism of the neonates. The present study was therefore undertaken to compare differences between the $\mathrm{L}$ and $\mathrm{H}$

*Reprint requests to Dr S. N. McCutcheon.

Present address: Department of Animal Science, Agricultural University, Wageningen, The Netherlands. 
lines in litter size (as measured by fetal number), fetal and placental weights and mammary gland weight. Mice of the $\mathrm{C}$ line were not included.

\section{Materials and Methods}

\section{Animals}

The study utilized female mice from the selection experiment described by Blair $\mathrm{et}$ al. (1989). In that experiment, 4 inbred strains of mouse (NOS, CHI, TSA and $\mathrm{C} 3 \mathrm{H}$ ) were crossed to provide a base population then divergent lines were established by selection for low or high litter mean IGF-1 concentrations. After 7 generations of selection, mice were randomly bred within the lines to produce the 8 th and 9 th generations (i.e. selection pressure was no longer applied).

Female mice from the 9 th generation ( 3 from each of $10 \mathrm{~L}$ and $10 \mathrm{H}$ litters) born over a 5 -day period were weaned and individually earmarked at a mean of 23 days of age. Pairs of litters (within line) were combined and housed in cages (6 females per cage) in a constant light schedule of $14 \mathrm{~h}$ light:10 h dark (lights on 06:00 h) and ambient temperature of $20^{\circ} \mathrm{C}$. Mice were given ad-libitum access to fresh water and a pelleted, complete diet (Feed Processing Centre, Massey University) throughout the study. Females were weighed weekly (at 10:00 h) commencing 26 days after weaning and continuing until they were placed with a male.

\section{Mating}

At a mean 70 days of age, females were randomly assigned within line to 10 fertile males of generation 8 ( 3 females per male). The only constraints on this assignment were that full- or half-sisters were not placed with the same male, and females were not placed with their own sire.

During a 15-day period after placement with males, females were examined between $09: 00 \mathrm{~h}$ and 12:00 $\mathrm{h}$ daily for the presence of vaginal plugs. Those not exhibiting plugs were then subjected to vaginal swabbing using the lavage method of Snell (1941). Vaginal smears were stained with $0.1 \%$ methylene blue and examined for the presence of spermatozoa. Females exhibiting a vaginal plug or presence of spermatozoa were recorded as having been mated, were weighed and transferred to nursery cages. Two females from each line were housed in each nursery cage.

Females which were not recorded as having been mated after 15 days remained in the original cages and those that subsequently proved to be pregnant were transferred in pairs to nursery cages. All females were retained until 18 days after the end of mating to ensure detection of any pregnancies.

\section{Blood sampling and dissection}

Females pregnant to a known mating date were anaesthetized with ether on Day 19 after mating (detection of vaginal plug/spermatozoa $=$ Day 1 ) and a $600-\mu l$ blood sample was withdrawn from the ophthalmic venous plexus as described by Riley (1960). Females were then killed by an ether overdose and carefully skinned. Mammary gland tissue was removed from the skin and weighed. No distinction was possible between mammary gland and the subcutaneous adipose tissue into which the gland grows. The abdominal cavity of the female was then opened and the pregnant uterus excised. Fetuses were removed from the uterus, dissected free of the fetal membranes, blotted dry and weighed (total litter weight). The placental discs were also dissected free of fetal membranes, blotted dry and a total weight recorded. Tissues were placed in pre-weighed foil envelopes as they were removed to minimize evaporative loss. Total weight of the maternal skin, carcass (including viscera) and empty uterus was recorded to provide an estimate of conceptus-free body weight of the dam.

Pregnant females for which no mating date was available were killed in late pregnancy and the number of fetuses recorded.

\section{Sample processing and assay}

Blood samples were transferred to heparinized microfuge tubes ( 9 i.u. sodium heparin per tube), stored on ice and within $1 \mathrm{~h}$ centrifuged at $3000 \mathrm{~g}$ and $4^{\circ} \mathrm{C}$ for $20 \mathrm{~min}$. Plasma was harvested and stored at $-20^{\circ} \mathrm{C}$ until assay. Plasma IGF-1 concentrations were determined by radioimmunoassay following acid-ethanol extraction using the procedure of Gluckman et al. (1983). The reference standard was recombinant human met-IGF-I (IMC batch 742.44) and assay sensitivity was $10 \mathrm{ng} / \mathrm{ml}$. Intra- and inter-assay coefficients of variation were 5.0 and $9.8 \%$ respectively.

\section{Statistical methods}

Effects of selection line on premating liveweights and the proportion of females pregnant within the 15-day mating period (logit-transformed) were assessed in all 60 mice by analysis of variance. Data from the pregnant mice (with or without known mating dates) were used to determine line effects on fetal number while only those data from females 
of known mating date were used for the analysis of other measures (e.g. fetal and placental weights, mammary gland weight). When appropriate, 'reproductive' values (including mammary gland weight) were adjusted to a common mating weight or conceptus-free body weight of the dam to determine the presence of selection line effects additional to those mediated via bodyweight. Analysis of variance models also accounted for the within-line effects of the dam's litter of origin and the sire to which she was mated (as appropriate). Homogeneity of within-line regressions was tested by the method of Searle (1971). When heterogeneous regressions occurred, the regression coefficients and their standard errors are reported. All statistical analyses were undertaken using the SAS statistical package (SAS, 1985). Probabilities given in the table and text are for two-tailed tests.

\section{Results}

During the 3 weeks before placement with the male, High-line females were $3 \cdot 2-3 \cdot 5 \mathrm{~g}(\simeq 14 \%)$ heavier than their L-line contemporaries $(P<0.001)$, with both lines exhibiting a gradual and parallel increase in liveweight over this period.

Table 1. Body weights and components of reproductive performance at Day 19 of gestation in female mice from lines selected for low or high plasma concentrations of insulin-like growth factor-1

\begin{tabular}{|c|c|c|c|c|c|c|c|c|}
\hline \multirow[b]{3}{*}{ Variable } & & & & & \multicolumn{4}{|c|}{ Significance of effects } \\
\hline & \multicolumn{4}{|c|}{ Selection line (mean \pm s.e.) } & \multicolumn{2}{|c|}{ Uncorrected } & \multicolumn{2}{|c|}{ Corrected $^{\mathrm{a}}$} \\
\hline & & Low & & High & Line & Litter $^{\mathbf{b}}$ & Line & Litter $^{b}$ \\
\hline All pregnant mice & & 24 & & 20 & & & & \\
\hline Fetuses per litter & $7 \cdot 5$ & $\pm 0 \cdot 3$ & $9 \cdot 3$ & \pm 0.4 & ** & NS & NS & NS \\
\hline Known mating dates & & $1 \overline{9}$ & & $1 \overline{4}$ & & & & \\
\hline Mating liveweight (g) & $20 \cdot 3$ & \pm 0.4 & $23 \cdot 1$ & \pm 0.5 & *** & NS & - & - \\
\hline Fetuses per litter & $7 \cdot 8$ & \pm 0.3 & $9 \cdot 3$ & \pm 0.5 & $*$ & NS & NS & NS \\
\hline Conceptus-free body weight (g) & $23 \cdot 3$ & \pm 0.3 & $26 \cdot 5$ & \pm 0.6 & **** & NS & - & - \\
\hline Total fetal weight $(\mathrm{g})$ & $8 \cdot 4$ & \pm 0.3 & $10 \cdot 9$ & \pm 0.6 & $* * *$ & $*$ & * & * \\
\hline Average fetal weight (g) & $1 \cdot 10$ & \pm 0.03 & $1 \cdot 18$ & \pm 0.03 & + & ** & * & $* *$ \\
\hline Total placental weight $(\mathrm{g})$ & 0.62 & \pm 0.03 & 0.84 & \pm 0.05 & $* * *$ & NS & + & NS \\
\hline Average placental weight (g) & 0.080 & $0 \pm 0.003$ & 0.092 & $2 \pm 0.005$ & $*$ & NS & * & NS \\
\hline Mammary gland weight (g) & $2 \cdot 42$ & \pm 0.09 & $2 \cdot 85$ & \pm 0.13 & **** & * & NS & $\dagger$ \\
\hline
\end{tabular}

${ }^{\mathrm{a} C}$ Corrected to common maternal weight, i.e. weight at placement with male (fetuses per litter, all pregnant mice), mating liveweight (fetuses per litter in mice pregnant to known mating dates) or conceptus-free body weight (other variables).

${ }^{b}$ Litter of origin within line.

NS, Not significant; $+P<0.10 ;{ }^{*} P<0.05 ;{ }^{* *} P<0.01 ;{ }^{* * *} P<0.001$.

Of the 60 mice placed with a male, $48(25 \mathrm{~L}, 23 \mathrm{H})$ conceived during the 15 -day mating period. The proportion of females becoming pregnant was not influenced by line, litter of origin, or the sire to which the female was mated $(P>0 \cdot 10)$. Four females $(1 \mathrm{~L}, 3 \mathrm{H})$ littered before they could be dissected while another $11(5 \mathrm{~L}, 6 \mathrm{H})$ conceived without exhibiting vaginal plugs or spermatozoa in vaginal smears. Only fetal number (at Day 19 of gestation) was assessed in the latter group. Thus 33 females $(19 \mathrm{~L}, 14 \mathrm{H})$ were pregnant to known mating dates and subjected to full dissection.

Fetal number was significantly influenced by line, $\mathrm{H}$-line females having an average $1 \cdot 5-1 \cdot 8$ $(19-24 \%)$ more fetuses than did L-line females $(P<0 \cdot 05$, Table 1$)$. The line effect was reduced to non-significance when fetal numbers were corrected to a common maternal liveweight (that at pairing with males on Day 70 ). Conceptus-free liveweight was significantly greater in $\mathrm{H}$-line than L-line females $(P<0.001)$ and in each line was about $3 \mathrm{~g}$ greater than mating weight.

Total fetal weight was also greater in $\mathrm{H}$-line than in L-line females $(P<0.001)$, partly because of their increased fetal number but also because average fetal weight was greater in the $\mathrm{H}$ line $(P<0 \cdot 10$, Table 1). Correction of average fetal weight to a common maternal conceptus-free bodyweight and/or fetal number therefore did not eliminate the significant effect of selection line. Within-line regressions of average fetal weight on fetal number were heterogeneous $(P<0.05)$. In 
the $\mathrm{L}$ line, average fetal weight declined with increasing litter size $(b=-0.062 \pm 0.019 \mathrm{~g} / \mathrm{fetus}$, $r=-0.63, P<0.01)$ but no such relationship was apparent in the $\mathrm{H}$ line $(b=0.001 \pm 0.018 \mathrm{~g} / \mathrm{fetus}$, $r=0.01, P>0 \cdot 10)$.

In addition to having heavier fetal weights, $\mathrm{H}$-line females also had increased total weights of placenta by $0.22 \mathrm{~g}$ or $35 \%(P<0.001)$. Despite the increased litter size in this line, average weight of the individual placental units was also greater $(P<0 \cdot 05)$. Correction to a common maternal conceptus-free bodyweight and/or litter size did not therefore remove the significant line effects on total or average placental weights. In contrast to fetal weights, regressions of average placental weight on fetal number were homogeneous between the lines.

$\mathrm{H}$-line females exhibited a $0.43 \mathrm{~g}(18 \%)$ greater mammary gland weight than did L-line females $(P<0.001)$, an effect which could be entirely accounted for by correction to a common maternal conceptus-free bodyweight. Among the $\mathrm{H}$-line females, mammary gland weight increased with number of fetuses $(b=0.169 \pm 0.066 \mathrm{~g} /$ fetus, $r=0.60, P<0.05)$ but there was no relationship in the L-line females ( $b=0.007 \pm 0.072 \mathrm{~g} /$ fetus, $r=-0.02, P>0.10)$.

Plasma concentrations of IGF-1 at Day 19 of gestation were $330.8 \pm 14.4$ (mean \pm s.e.) $\mathrm{ng} / \mathrm{ml}$ in the L-line and $368.9 \pm 22.5 \mathrm{ng} / \mathrm{ml}$ in the $\mathrm{H}$-line females $(P>0 \cdot 10)$. Correction to common maternal IGF-1 values did not eliminate the significant effects of line on maternal bodyweight, litter size, or weights of the fetuses, placentae and mammary gland.

\section{Discussion}

It is apparent from this study that significant correlated responses in reproductive performance and mammary gland growth have accompanied divergent selection on the basis of plasma IGF-1 concentrations at 42 days of age in these mice. These responses were measured at Day 19 of gestation to permit maximum fetal growth while ensuring that as few as possible of the females littered before the date of dissection.

Although circulating concentrations of $\mathrm{IGF}-1$ were about $40 \mathrm{ng} / \mathrm{ml}(12 \%)$ higher in $\mathrm{H}$-line than L-line females at Day 19 of gestation, these differences were not significant. Nor was there any relationship between $\mathrm{IGF}-1$ values and maternal bodyweight or reproductive performance. We have previously examined the ontogeny of plasma IGF-1 in these lines and its relationship with body growth (unpublished data). Differences between the lines in plasma IGF-1 values are apparent as early as 21 days of age and are associated with marked differences in growth rate, particularly during the pubertal growth acceleration. Thereafter, rate of divergence between the lines in body growth is reduced although divergence in plasma IGF-1 is maintained. This implies that many of the differences in reproductive performance observed in this study can be traced to differences in maternal body growth during the pubertal period.

Fetal number was increased by $19 \%$ in the $\mathrm{H}$ line and all fetuses were apparently healthy. Given that fetal number was determined 1-4 days before parturition, this would undoubtedly have translated into an increased number of live births. Differences between the lines in litter size could be accounted for by differences in maternal liveweight. This supports the view that elevated plasma IGF-I concentrations in the $\mathrm{H}$-line mice improve litter size (and presumably ovulation rate) by increasing liveweight of the dam at mating rather than by a direct effect on the reproductive system. However, plasma IGF-1 concentrations at the time of conception were not measured and, given the confounding of line differences in body weight and plasma IGF-1 values, the possibility of a direct effect on the reproductive system cannot be excluded. Ovarian function is influenced by IGF-1, perhaps of granulosa cell origin (Adashi et al., 1984, 1985; Davoren et al., 1985), and there could also have been differences between the lines in intraovarian IGF-1 concentration.

Despite their increased fetal numbers, $\mathrm{H}$-line females also exhibited increased weights of individual fetuses and placental units. Effects of fetal genotype and uterine environment provided by the dam were totally confounded in this study. Hence it is not possible to determine whether the 
increased weight of the fetuses and placentae in the $\mathrm{H}$-line was a function of fetal capacity to grow in utero or ability of the dam to supply nutrients for fetal and placental growth. Studies involving reciprocal crossing of the lines or embryo transfer will be required to separate these effects. However, the fact that fetal weight declined with increasing litter size in the L line, but was independent of litter size in the $\mathrm{H}$ line, implies that differences in maternal ability to supply nutrients to the gravid uterus are involved. Fetal growth is generally considered to be constrained by the supply of nutritional substrates to the uterus. The inverse relationship between litter size and weight of individual fetuses in the $\mathrm{L}$ line is evidence for such a constraint. In the $\mathrm{H}$ line no such relationship was apparent, suggesting that dams of this line were better able to supply nutrients to their fetuses. Alternatively, it may be that $\mathrm{H}$-line fetuses are genetically predisposed to more rapid growth in utero, perhaps as a result of their having higher IGF-1 concentrations. There is increasing evidence that IGF-1 is involved in regulating fetal growth (Gluckman \& Brinsmead, 1976; Ashton et al., 1985; Gluckman \& Barry, 1988) but IGF-1 concentrations in L- and H-line fetal mice have yet to be measured. Whatever the mechanism, improved fetal growth and birthweights in H-line young may contribute to their superior body growth in early post-natal life (unpublished data).

Mammary gland weight was also superior in the $\mathrm{H}$-line compared with L-line females. Moreover, gland weight increased with number of fetuses in the $\mathrm{H}$ line but not in the $\mathrm{L}$ line. These effects were apparently related to differences in maternal bodyweight with no independent effect of maternal plasma IGF-1.

Finally, it should be noted that the proportional increases in litter size (19-24\%), fetal weight $(30 \%)$ and mammary gland weight $(18 \%)$ of $\mathrm{H}$-line $v s$ L-line mice were all greater than the corresponding increases in mating liveweight $(14 \%)$. Since the maintenance costs of breeding females are generally proportional to their metabolic liveweight this suggests that, in domestic animals, selection on the basis of plasma IGF-1 concentrations at an early age could lead to substantial responses in productive efficiency.

This work was supported by the C. Alma Baker Trust and the Medical Research Council of New Zealand. R.A.S. is the recipient of a Massey University Postdoctoral Fellowship.

\section{References}

Adashi, E.Y., Resnick, C.E., Svoboda, M.E. \& Van Wyk, J.J. (1984) A novel role for somatomedin-C in the cytodifferentiation of the ovarian granulosa cell. Endocrinology 115, 1227-1229.

Adashi, E.Y., Resnick, C.E., Svoboda, M.E. \& Van Wyk, J.J. (1985) Somatomedin-C synergizes with folliclestimulating hormone in the acquisition of progestin biosynthetic capacity by cultured rat granulosa cells. Endocrinology 116, 2135-2142.

Ashton, I.K., Zapf, J. Einschenk, I. \& MacKenzie, I.Z. (1985) Insulin-like growth factors (IGF) 1 and 2 in human foetal plasma and relationship to gestational age and foetal size during midpregnancy. Acta endocr., Copenh. 110, 558-563.

Blair, H.T., McCutcheon, S.N., Mackenzie, D.D.S., Gluckman, P.D. \& Ormsby, J.E. (1987) Variation in plasma concentration of insulin-like growth factor-1 and its covariation with liveweight in mice. Aust. $J$. biol. Sci. 40, 287-293.

Blair, H.T., McCutcheon, S.N., Mackenzie, D.D.S., Gluckman, P.D., Ormsby, J.E. \& Breier, B.H. (1989) Responses to selection for high or low concentrations of insulin-like growth factor-1 in mice. Genet. Res. (in press).

Davoren, J.B., Hsueh, A.J.W. \& Li, C.H. (1985) Somato- medin C augments FSH-induced differentiation of cultured rat granulosa cells. Am.J.Physiol. 249, E26-E33.

Gluckman, P.D. \& Barry, T.N. (1988) Relationships between plasma concentrations of placental lactogen, insulin-like growth factors, metabolites and lamb size in late gestation ewes subject to nutritional supplementation and in their lambs at birth. Dom. Anim. Endocr. 5, 209-217.

Gluckman, P.D. \& Brinsmead, M.W. (1976) Somatomedin in cord blood: relationship to gestational age and birth size. J. clin. Endocr. Metab. 43, 1378-1381.

Gluckman, P.D., Johnson-Barrett, J.J., Butler, J.H., Edgar, B.W. \& Gunn, T.R. (1983) Studies of insulinlike growth factor-I and II by specific radioligand assays in umbilical cord blood. Clin. Endocr. 19, $405-413$.

Riley, V. (1960) Adaption of orbital bleeding technique to rapid serial blood studies. Proc. Soc. exp. Biol. Med. 104, 751-754.

S.A.S. (1985) Statistical Analysis Systems. SAS Institute Inc., Cary.

Searle, S.R. (1971) Linear Models. Wiley, New York.

Snell, G.D. (1941) Biology of the Laboratory Mouse. Blakiston, Philadelphia.

Received 8 February 1989 